\title{
National diabetes strategy and diabetes epidemiology in Norway
}

\author{
Tore Julsrud Berg \\ Endokrinologisk avdeling, Oslo universitetssykehus HF, Aker sykehus, P.b. 4959 Nydalen, 0424 Oslo \\ E-mail: t.j.berg@medisin.uio.no
}

Norway has a unique opportunity to study the risk factors, incidence and prevalence of diabetes and its complications. So how are we performing at present? This volume of Norsk Epidemiologi will give you an answer.

The Ministry of Health and Care Services published in 2006 a "National strategy for diabetes 2006-10". This strategy was prolonged until 2012. What are the results of this priority of diabetes by the politicians?

First of all a new reform from January 2012 ("Samhandlingsreformen") which includes both an act on public health ("Folkehelseloven") and an act on health and care in the local municipalities ("Helse- og omsorgstjenesteloven") aim to improve the primary prevention of diseases like diabetes, improve the cooperation between the primary - and secondary health care and increase the resources of health care in the local municipalities. The focus is on primary prevention instead of the repair of diseases at a late stage. Another goal is to involve the patients in the planning and performance of health care. The cornerstones of the reform are the Local Medical Centre ("Lokalmedisinske senter") and the Lifestyle Centre ("Frisklivssentraler") together with a health focus in all the planning and activities of the local municipalities.

This reform also creates a momentum to improve the health care for people with established diabetes. Diabetes and the "National Diabetes Strategy" has in many ways served as an inspiration for the reform and the diabetes strategy work group has been involved in the planning of it.

One goal is to identify people with undiagnosed diabetes due to their more than doubled risk of macrovascular disease and for many existing microvascular diseases. How many they are in Norway is uncertain with numbers varying from $22-100 \%$ of known diabetes. More than 150000 persons have tested their risk of diabetes by the self score test www.diabetesrisiko.no, a translation into Norwegian of the Finnish FindRisk test.

"National clinical guidelines: Diabetes" for health professionals (www.helsebiblioteket.no/retningslinjer/ diabetes) and a "translation" of this into a text made for patients with diabetes and relatives (www. helsenorge.no/diabetes) have both been great successes with 7000 and 60000 paper copies sent out respectively and high numbers of searches on the internet. The "National clinical guidelines: Diabetes" has its main focus on secondary and tertiary prevention of diabetes. It is normative and is now being gradually revised using the GRADE methodology rating quality of evidence and grading strength of recommendations.

The Regional Health Authorities are governed by 13 parameters ("Styringsparametre") of which one is lower extremity amputations due to diabetes. In 2011 the Norwegian Patient Registry noted 441 major and minor amputations due to diabetes. A new code for the clinical assessment and care for diabetic foot ulcers was implemented in 2012 (QDX10"Stell av diabetiske fotsår") with the possibility to increase reimbursement (DRG) at a later stage. Information leaflets for patients at different risks of developing foot ulcers are now translated from the originals made by NHS-Scotland. These will be distributed on internet and paper.

As pointed out by Jenum in this volume (1), applying the diagnostic criteria from the HAPO study will possibly double the prevalence of gestational diabetes in Norway. WHO is expected to announce their new diagnostic criteria this year. A working group in the National Directorate of Health are at present reviewing the diagnostic criteria and the plan of care for gestational diabetes.

People with diabetes have been an increasingly important collaborator for the "National Diabetes Strategy". The Diabetes Association receives 6.5 mill. NOK in 2013 as support for their motivational groups, the telephone advisory system ("Diafonen") the Diabetes Risk test and their important work on diabetes among ethnic minorities.

The Norwegian Directorate of Health have just recently established a National Advisory Board on Diabetes ("Nasjonalt fagråd for diabetes") to aid its work in the field of diabetes in addition to the 2.5 employees working with diabetes in the Directorate.

What is the prevalence of diabetes in Norway and what is the condition regarding late complications, HbA1c and hypoglycaemia? Today we do not have answers to these questions. We all admire the Norwegian Childhood Diabetes Registry, a prospective, population-based, nationwide registry which systematically register all incident cases of childhood diabetes, and systematically monitors the outcome of diabetes care in children and adolescents. This register, as shown in Skrivarhaug's paper in this volume (2), includes 95\% of patients with diabetes aged eighteen years or younger, a total of 2567 patients.

The local municipalities are now obliged to monitor the outcome of chronic diseases like diabetes. At present the best way to monitor the quality of the health care delivery and outcome in diabetes is to encourage the general practitioners to use the NOKLUS diabetes 
file system and report to the Norwegian Diabetes Registry for Adults. See Cooper's paper in the present volume (3).

In 2008 The Ministry of Health and Care Services instructed the Regional Health Authorities to use electronic diabetes patient files i.e. "NOKLUS diabetes fagsystem". To obtain data from all patients with diabetes work has been started to consider establishing The Norwegian Diabetes Registry for Adults and the Norwegian Childhood Diabetes Registry as nonconsent based registers. So far we are gaining much knowledge on diabetes in Norway from the national prescription database described by Berg and Strøm in this volume (4).

The National project on quality indicators on health has diabetes as one of its four prioritised areas. Norway is a small and relative homogenous country. Its national health registers and the medical registry of quality in health care have a great potential to serve as knowledge bases for improvements of the health care and epidemiological research together with cohort studies and biobanks. We should be able to identify the interactions of genes and environment by genome- and environment-wide associations as recently published from the NHANES study (5).

When reading the present volume of Norsk Epidemiologi I am impressed by the variety of research fields covered in a country with five million inhabitants. This is important for Norwegian clinicians and desicion makers. The variety could however, be a weakness indicating a lack of focus of limited resources making Norwegian epidemiological research inable to present research results of international importance. The brilliant long-term work by Njølstad's group in Bergen, here presented by Søvik's paper (6), disproves this thought.

A search on PubMed on the search words "diabetes epidemiology Norway 2002" vs. "diabetes epidemiology Norway 2012" by my gentle selection, showed 12 vs. 44 search results, respectively. From my experience this reflects a clear and joyful increase in the epidemiological research on diabetes in Norway. The present volume also documents the high quality of many of the research areas. Enjoy!

\section{REFERENCES}

1. Jenum AK, Richardsen KR, Berntsen S, Mørkrid K. Gestational diabetes, insulin resistance and physical activity in pregnancy in a multi-ethnic population - a public health perspective. Norsk Epidemiologi 2013; 23 (1): 45-54.

2. Skrivarhaug T. Norwegian Childhood Diabetes Registry: Childhood onset diabetes in Norway $1973-2012$. Norsk Epidemiologi 2013; 23 (1): 23-27.

3. Cooper JG, Thue G, Claudi C, Løvaas K, Carlsen S, Sandberg S. The Norwegian Diabetes Register for Adults - an overview of the first years. Norsk Epidemiologi 2013; 23 (1): 29-34.

4. Berg C, Strøm H. The Norwegian Prescription Database (NorPD) as a data source for diabetes research. Norsk Epidemiologi 2013; 23 (1): 109-110.

5. Patel CJ, Chen R, Kodama K, Ioannidis JPA, Butte AJ. Systematic identification of interaction effects between genome- and environment-wide associations in type 2 diabetes mellitus. Hum Genet 2013; 132 (5): 495-508.

6. Søvik O, Irgens HU, Molnes J, Sagen JV, Bjørkhaug L, Ræder H, Molven A, Njølstad PR. Monogenic diabetes mellitus in Norway. Norsk Epidemiologi 2013; 23 (1): 55-60. 